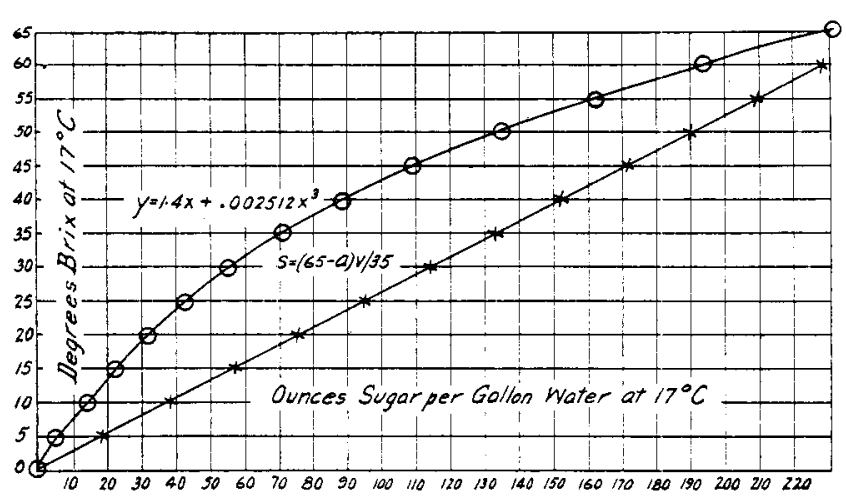

of the formula in Table VI; namely, $y=I .4 x+$ $0.002512 x^{3}$, where $x=$ degrees Brix of syrup and $y=$ the ounces of sugar added per gallon of water at $I 7^{\circ} \mathrm{C}$. This last formula was obtained by interpolation of experimental results.

One of the practical applications of these experimental results is shown in connection with fruit jellymaking. In determining the amount of sugar necessary to add to a fruit juice or extract for jelly making no compensation need be calculated for extracts of less than $15^{\circ}$ Brix. The right amount of sugat in ounces (more than $60^{\circ}$ and less than $72^{\circ}$ Brix) may be obtained by adding 1.8 times the number of ounces of fruit extract. ${ }^{1}$

\begin{tabular}{|c|c|c|c|}
\hline \multirow[b]{2}{*}{$\begin{array}{l}\text { Per cent } \\
\text { Sugar } \\
i{ }^{\circ} \mathrm{C} \text {. }\end{array}$} & \multicolumn{3}{|c|}{$\begin{array}{l}\text { OUNCES SLGaR PER GaILON OF WATER AT } 17^{\circ} \mathrm{C} \text {. } \\
\text { Calculated by MeNair }\end{array}$} \\
\hline & $\begin{array}{c}\text { Observed } \\
\text { by } \\
\text { Bitting }\end{array}$ & $\begin{array}{l}y=1.4 x+ \\
0.002512 x^{3} \\
\text { (where } x= \\
\text { degree Brix) }\end{array}$ & $\begin{array}{c}\text { Calculated by } \\
\text { Cruess and McNair } \\
s=(65-a) v / 35\end{array}$ \\
\hline 0. & 0 & $\underline{0}$ & 0 \\
\hline & 78 & $\begin{array}{r}7.064 \\
514\end{array}$ & 19.0 \\
\hline 15. & $\begin{array}{l}14.0 \\
23.5\end{array}$ & 22.728 & 57.1 \\
\hline 20 & 30.8 & 32.096 & 76.2 \\
\hline 25 & $\begin{array}{l}44.5 \\
57.12\end{array}$ & $\begin{array}{l}43 . \\
55 .\end{array}$ & $\begin{array}{r}95.2 \\
114.3\end{array}$ \\
\hline 35. & 71.75 & 70.952 & 133.4 \\
\hline & $\begin{array}{r}88.8 \\
109.0\end{array}$ & $\begin{array}{r}88.768 \\
109\end{array}$ & 352.4 \\
\hline & 133.3 & $\begin{array}{l}134.9 \\
1.9\end{array}$ & 190.7 \\
\hline & $\begin{array}{l}163.9 \\
200.0\end{array}$ & $\begin{array}{l}162.184 \\
102.502\end{array}$ & 209.8 \\
\hline & 200.0 & & 247.9 \\
\hline & . & 273 & \\
\hline
\end{tabular}

The author would like to express his gratitude to Professor T. Brailsford Robertson and Assistant Professor William V. Cruess for assistance during this investigation.

P. O. BOX 125

BERKELEY, CALIFORNIA

\section{BANANA STALKS AS A SOURCE OF POTASH}

By H. E. Billings AND A. W. Christie

Received November 27, 1916

The great demand for potash salts during the past two years has led to the investigation of many materials, occurring either naturally or as waste products, with a view to the possible commercial utilization of their potash content. Ellis, ${ }^{2}$ in an ash analysis of the banana stalk, called attention to the surprisingly high percentage of potash in this material. In every large American city thousands of these stalks are discarded as garbage weekly. The

'J. B. MeNair, "Failures in Jelly Making and Their Remedies," The California Cultivator, No, 26, 46 (1916), 736.

2 J. Soc. Chem. Ind., 35 (1916), 456. possible treatment of such material for the recovery of its potassium suggested the following experimental work.

XATLRE OF MATERIAL-The material used comprised individual banana stalks obtained from fruit markets after removal of the fruit. The stalk is of an endogenous nature, with its vascular bundles so arranged as to form a collection of tubes through which the sap flows. Such a structure permits of very rapid drying. The stalks varied in weight from 2 to 4 lbs., averaging about 3 lbs, and were found to be very constant in moisture, ranging from 9 I. 2 to 92.6 per cent water

COMPOSITION OF DRY MATTER-The stalks were chopped into pieces about one in. long and dried in the oven. The dried samples were exceedingly friable and easily broken or ground in a mortar. A sample was analyzed for fertilizing constituents with the following results:

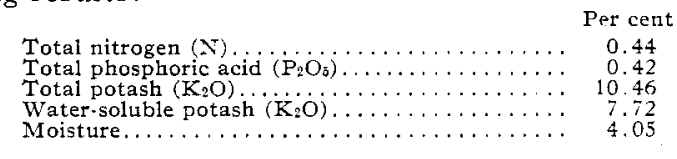

The dry matter is as rich in potash as commercial kainit and may be considered nearly as valuable, since 74 per cent of the potash is soluble in water. Were this material used as a fertilizer, it is reasonable to assume that the organic matter would in time decompose in the soil with the formation of humus, resulting in the subsequent release of the remainder of the potash in an available condition. This material also approximates the composition and value of dried kelp, ${ }^{1}$ which at the present time is being used to a considerable extent as a filler in commercial fertilizers. In certain respects, the material under consideration is probably superior to kelp for this purpose. Especially to be noted is the fact that banana stalks contain only very slight amounts of sodium and chlorine whereas kelp contains such quantities as to throw it into the class of kainit or other chlorinated salts.

EXTRACTION OF SALTS-Weighed amounts of the dry matter were charred sufficiently to destroy organic matter and the resulting char leached with 'successive small portions of distilled water. About I 6 per cent of the dry matter was recovered in the form of watersoluble salts. A maximum yield was obtained with water representing 5 times the weight of original dry matter. The salts were dried to constant weight at $100^{\circ} \mathrm{C}$, and analyzed with the following results:

\begin{tabular}{|c|c|}
\hline & Per cent \\
\hline Silica $\left(\mathrm{SiO}_{2}\right) \ldots{ }_{\text {Iron }}{ }_{\text {axide }} \mathrm{Fe}_{2} \mathrm{O}_{3}$ & 2.81 \\
\hline $\begin{array}{l}\text { Iron oxide }\left(\mathrm{Fe}_{2} \mathrm{O}_{3}\right) \\
\text { Alumina }\left(\mathrm{Al}_{2} \mathrm{O}_{3}\right) \ldots\end{array}$ & $\begin{array}{l}\text { None } \\
\text { None }\end{array}$ \\
\hline Manganese oxide $\left(\mathrm{Mn}_{3} \mathrm{O}_{4}\right)$ & None \\
\hline ime $(\mathrm{CaO}) \ldots \ldots \ldots \ldots$ & 0.12 \\
\hline Magnesia (MgO). & 0.07 \\
\hline Potash $\left(\mathrm{K}_{2} \mathrm{O}\right)$.. & 64.23 \\
\hline$\ldots \ldots \ldots \ldots \ldots \ldots \ldots$ & 0.46 \\
\hline$\ldots \ldots \ldots \ldots \ldots \ldots$ & 4.17 \\
\hline$\cdots \cdots$ & 26.11 \\
\hline $\begin{array}{l}\text { Chlorine (Cl) } \\
\text { Phosphoric acid }\end{array}$ & $\begin{array}{l}1.57 \\
0.34\end{array}$ \\
\hline ta & 99.88 \\
\hline
\end{tabular}

The above figures show that the leached salts consist of over 90 per cent potassium carbonate. This salt should command a price equal to that quoted for any

1 Calif. Agr. Expt. Sta., Bull. 248. 
85 per cent potassium carbonate on the market, which in recent quotations was close to one dollar per pound. Every ton of fresh material will yield 27 pounds of this 90 per cent potassium carbonate.

METHODS OF HANDIING-By pressing the chopped stalks in a small cider press it was found possible to remove 73 per cent of the original moisture. This extracted juice was somewhat colored by dissolved organic matter, showed a specific gravity of $I .0 \mathrm{I}$ and contained I per cent potash. Since the original stalk contained approximately I per cent potash and 92 per cent water, the potash extracted by pressing represents nearly 70 per cent of the total. Probably the most efficient method of recovery, however, is to char the material. There are practically no difficulties encountered in this process. The nature of the material is a great aid in its own combustion. When heated, it begins to glow like charcoal and under a forced draft will burst into flame and support combustion, burning to an ash. In the presence of a free supply of air, there is enough heat furnished after the first glow begins to complete the charring without the further application of heat. This property can be made use of by placing the chopped raw material over a grating in a tall cylindrical heater, beneath which is a flame. The material in contact with the flame after drying begins to char and with the forced draft arising from the height of the cylinder, will furnish heat from its own combustion sufficient to dry the green material above it. Thus, by feeding the raw material in at the top and drawing off the ash at the bottom, a continuous yield of char can be obtained. This char can then be extracted with distilled water by any suitable means and the liquor evaporated to dryness. The dried and ground salts are clean and white and only slightly hygroscopic.

In large cities where considerable amounts of these stalks are available, it seems likely that some scheme of collection or of segregation at the garbage incinerators could be employed at small expense. The subsequent recovery of the potash has already been shown to be very simple and inexpensive, requiring no special or expensive apparatus. As stated above, one ton of fresh material should furnish in the neighborhood of $\$ 25.00$ worth of salts at the present market prices. This would seem to justify an expense for collection of about one cent per stalk (600 to 700 stalks make a ton), and still yield a fair margin of profit after deducting the nominal expense of treatment. The method of recovery lends itself readily to small scale manufacture and would in all probability be most practicable under such conditions.

$$
\text { SUMMARY }
$$

I-Dried banana stalks contain as much potash as kainit and compare favorably with dried kelp as filler for commercial fertilizer.

II-Charring and leaching of banana stalks yield 27 lbs. of 90 per cent potassium carbonate per ton.

III-The possibility of collection and treatment on a small scale is suggested.

Division OF Agricultural ChEMISTRY
AgRICULTURAL EXPERIMENT STATION

UNIVERSITY OF CALIFORNIA, BEREELEY

\section{THE RELATIVE AVAILABILITY OF ACID PHOSPHATE AND RAW ROCK PHOSPHATE IN INDIANA FIELD TESTS ${ }^{1}$}

By S. D. CONNER

Approximately 80 per cent of the soils of Indiana are in need of phosphate fertilizers. The Purdue Experiment Station has been conducting field experiments testing the relative merits of acid phosphate and raw rock phosphate since I904. Up to the end of the I9I5 season 82 tests had been carried out, in which acid phosphate could be compared to raw rock phosphate. These tests were made on six different experiment fields in various parts of the state on a variety of soil types, and have been running from 2 to I o years. In addition, tests were made in cooperation with farmers in five different counties on other soils. Table I presents a general summary of all these experiments. These tests are believed to give a fair comparison of the use of the two phosphates under average Indiana field conditions, with various crops and during different seasons on a large number of soil types. The treatments have been the same for the various plots under investigation, except that some have had acid phosphate, some have had raw rock phosphate and some have had no phosphate. As a result of the 82 tests it shows that without question it pays to use acid phosphate on these soils. Raw rock phosphate has also shown a profit, but much smaller than for acid phosphate.

The acid phosphate contained i 6 per cent available phosphoric acid and has been valued at $\$ 16.00$ per ton. The raw rock phosphate was brown Tennessee rock containing 28 per cent total phosphoric acid and has been valued at $\$ 7.00$ per ton.

Tabie I-Summary of All Experiments in which Acid Phosphath and Raw Rock Phosphate Have Benn Compared

(Average of Eighty.two Tests with Various Crops in Indiana)

\begin{tabular}{|c|c|c|c|c|c|c|c|}
\hline $\begin{array}{l}\text { Crop } \\
\text { (No. of } \\
\text { Tests) }\end{array}$ & Phosphate & Yield & Inc & $\begin{array}{l}\text { s per Ac } \\
\text { Phos- } \\
\text { phate } \\
\text { (lbs.) }\end{array}$ & $\begin{array}{c}\text { Value } \\
\text { of } \\
\text { increase } \\
(a)\end{array}$ & $\begin{array}{l}\text { Cost } \\
\text { of } \\
\text { Phos- } \\
\text { phate }\end{array}$ & $\begin{array}{c}\text { Profit } \\
\text { or } \\
\text { loss }\end{array}$ \\
\hline Lorn (36), & $\begin{array}{l}\text { Aci } \\
\text { Ra } \\
\text { No }\end{array}$ & $\begin{array}{l}43.0 \\
42.2 \\
37.5\end{array}$ & & $\begin{array}{l}190.5 \\
532.0\end{array}$ & $\begin{array}{r}2.95 \\
2.52\end{array}$ & $\begin{array}{r}\$ 1.52 \\
1.86\end{array}$ & $\begin{array}{r}\$ 1.43 \\
0.66\end{array}$ \\
\hline Vheat (33).. & $\begin{array}{l}\text { Acid } \\
\text { Raw rock } \\
\text { None }\end{array}$ & $\begin{array}{l}15.2 \\
12.8 \\
10.9\end{array}$ & & & $\begin{array}{l}4.63 \\
2.12\end{array}$ & $\begin{array}{l}1.52 \\
1.86\end{array}$ & \\
\hline hay & $\begin{array}{l}\text { Acid } \\
\text { Raw rock } \\
\text { None }\end{array}$ & $\begin{array}{l}2998 \text { lbs. } \\
2773 \text { lbs. } \\
2678 \text { lbs. }\end{array}$ & $\begin{array}{r}32 \\
9\end{array}$ & & $\begin{array}{l}1.60 \\
0.47\end{array}$ & $\begin{array}{l}1.52 \\
1.86\end{array}$ & $\begin{array}{r}0 \\
-1\end{array}$ \\
\hline Potatoes (4) & $\begin{array}{l}\text { Acid } \\
\text { Raw rock } \\
\text { None }\end{array}$ & $\begin{array}{r}112.0 \text { bu. } \\
94.2 \text { but. } \\
82.6 \text { bu. }\end{array}$ & $\begin{array}{l}29 \\
11\end{array}$ & $\begin{array}{r}500 \\
1000\end{array}$ & $\begin{array}{r}14.70 \\
5.80\end{array}$ & $\begin{array}{l}4.00 \\
3.50\end{array}$ & $\begin{array}{r}10.70 \\
2.30\end{array}$ \\
\hline$=(82)$ & & & & 545 & $\begin{array}{l}4.0 \\
2.2\end{array}$ & 1 . & $\begin{array}{l}2.42 \\
0.38\end{array}$ \\
\hline
\end{tabular}

(a) Value of increase inciudes value of corn stover and wheat straw.

(b) Average length of time tests have been running, 3.47 yrs.

The following crop values were used in calculating values of increase:

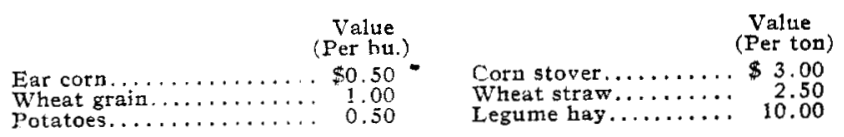

1 Presented at 53rd Meeting of American Chemical Society. This paper is based largely upon data published in Indiana Experiment Station Bull. 187, by A. T. Wiancko and S. D. Conner. Statistics of each crop and full particulars of the experiments may be found in that bulletin. 